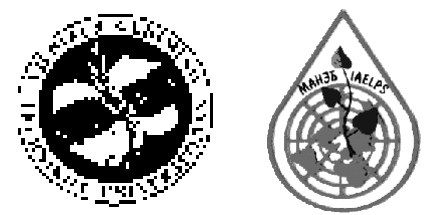

\title{
АНАЛИЗ СЦЕНАРИЕВ ТЕРРОРИСТИЧЕСКИХ АКТОВ С ПРИМЕНЕНИЕМ БИОАГЕНТОВ И ОЦЕНКА ВЕРОЯТНОСТИ ИХ ИСПОЛЬЗОВАНИЯ В КАЧЕСТВЕ БИОЛОГИЧЕСКОГО ОРУЖИЯ
}

\author{
С. В. Косырев, И. В. Свитнев, А. Г. Папин \\ Получено 09.02.2005; принято 21.03.2005
}

\begin{abstract}
Аннотация. Для того чтобы оценить масштаб и реальность биологического терроризма, в статье рассматривается один из вариантов террористического применения спор сибирской язвы. Рассматривается предполагаемый сценарий - в Санкт-Петербурге рядом со стадионом «Петровский» проезжает грузовик и в течение 30 секунд распыливает споры сибирской язвы. Представлены результаты моделирования такого случая.

Авторы попытались представить классификацию микроорганизмов как потенциальных объектов биологического оружия. Анализ критериально-рейтингового подхода к оценке вероятности использования биоагентов в качестве биологического оружия показал, что все биоагенты можно разделить на три группы. При этом необходимо сформулировать основные критерии, определяющие вероятность использования биоагентов в качестве биологического оружия и степень выраженности каждого из этих показателей. Таким образом, потенциальной угрозе биотеррористической атаки подвергаются объекты с большим скоплением людей, а наиболее вероятными биоагентами являются оспа, чума, сибирская язва, ботулизм, геморрагические лихорадки. Для выявления и оценки обстановки, возникающей при совершении террористических актов с применением биоагентов, необходимо разработать программный комплекс, позволяющий в несколько раз сократить время работы на этапе принятия решения по защите населения и ликвидации последствий биологического заражения.
\end{abstract}

Ключевые слова: биологический терроризм, биологическое оружие, сибирская язва, микроорганизмы, классификация биоагентов.

\section{ANALYSIS OF TERROR ACT SCENARIOS USING BIO-AGENTS AND EVALUATION OF PROBABILITY TO USE THEM AS BIOLOGICAL WEAPON}

\author{
S. V. Kosyrev, I. V. Svitnev, A. G. Papin \\ Received 9 Feb 2005; accepted 21 Mar 2005
}

\begin{abstract}
With the aim of evaluating possibility and spread of biological terrorism, the paper concentrates on one of the scenarios of possible application of Siberian sore. The authors are modeling a situation when an automobile passes near the stadium "Petrovskiy" in Sank-Petersburg and during the time period of 30 seconds spreads spores of Siberian sore. Modeling results are presented in the paper.

The authors try to present classification of microorganisms as potential objects for biological weapon. Analysis of the possibility to use bio-agents as biological weapon relied on some criteria, and they show that all bio-agents can be divided into some groups. More than that, it is necessary to formulate the main criteria which could express probability to use bio-agents as biological weapon. Thus objects with big concentrations of people are the most dangerous in the sense of attack by biological weapon. With the aim of determining a situation which appears in the case of terror acts with the use of bio-agents, it is necessary to create a complex program which would enable to save time when deciding how to protect inhabitants and eliminate the consequences of biological contamination.
\end{abstract}

Keywords: biological terrorism, biological weapon, Siberian sore, microorganisms, classification of bio-agents. 


\section{1. Введение}

Терроризм, все более набирающий силу в последние годы, становится характерной чертой развития мировой цивилизации в первом десятилетии XXI столетия. По оценкам экспертов, в настоящее время в мире действует более 600 крупных террористических организаций, многие из которых имеют транснациональный характер. Исходя из того, что даже самые развитые государства современного мира уязвимы перед биотеррористами, можно прогнозировать самые различные террористические акты и их последствия для мирного населения.

В качестве объектов атаки в наибольшей степени приемлемы крупные торговые центры, метро в часы «пик», рынки, различные праздничные мероприятия и т. п., отличающиеся большим скоплением людей. Так, если в течение 15 минут вблизи объекта атаки на высоте 15-20 м с подветренной стороны распылить около 4 млрд. спор сибирской язвы, то может быть создана смертельная концентрация аэрозоля. Однако размер большинства аэрозольных частиц, содержащих споры, будет превышать 10 микрометров, поэтому маловероятно, что они достигнут легочную (альвеолярную) ткань человека. Наибольшую опасность для биообъекта представляют частицы, диаметр которых в два раза меньше и которые свободно проходят через дыхательные пути и вызывают заражение организма. Проведенные экспертами расчеты показали, что для создания концентрации в 4 млрд. спор таких размеров потребуется распылить в воздухе в общей сложности 80 млрд. спор. Получение такого количества спор требует всего лишь нескольких литров биологического раствора со штаммом сибирской язвы, который скрытно может быть доставлен к месту теракта. При обеспечении оптимальных условий распыления указанного количества биологических агентов заражению подвергается около 4 млн. человек. Число погибших и выздоровевших в значительной степени будет зависеть от времени, прошедшего с момента заражения до начала оказания медицинской помощи. В случае массовых заболеваний при современной организации медицинского обслуживания населения своевременное лечение многих тысяч людей является делом довольно сомнительным. Еще более сложной задачей может стать спасение людей при их заражении тифом, паратифом, оспой, чумой. Кроме того, возможен сценарий, когда террористический акт совершается с использованием возбудителей болезней, передающихся от человека к человеку при непосредственном контакте (воздушнокапельным путем). Такими являются оспа и геморрагические лихорадки. Например, если террорист, заблаговременно прошедший вакцинацию, или смертник-шахид во время полета на воздушном лайнере незаметно распылит в салоне корабля вирусы оспы или чумы, то несколько сотен ничего не подозревающих пассажиров, заразившись, сами через определенное время станут «ходячим» биооружием и создадут примерно такое же число очагов заболеваний. Разрастаясь в геометрической прогрессии, эпидемия через короткое время приобретет огромные масштабы [1].

\section{2. Математическое моделирование применения биоагентов в качестве биологического оружия}

Для того чтобы оценить масштаб и реальность биологического терроризма, рассмотрим один из вариантов террористического применения спор сибирской язвы. Предположим, что в СанктПетербурге рядом со стадионом «Петровский» проехал грузовик, в течение 30 секунд распыливший споры сибирской язвы. На стадионе в это время находилось около 23 тыс. болельщиков, наблюдавших за футбольным матчем. Поскольку аэрозоль не обладает ни цветом, ни запахом, обнаружить его будет практически невозможно. Математическое моделирование последующих событий показало, что в течение 10 дней после подобного террористического акта заболеет более 6,5 тыс. человек, из которых около 1,3 тыс. погибнут. Первые случаи летальных исходов будут отмечены через 3 дня, а этиология заболеваний будет выявлена на 5-й день после террористического акта. Профилактическое назначение антибиотиков понадобится приблизительно для 70 тыс. человек, причем значительная часть пострадавших не сможет получит их своевременно. Попытки классифицировать микроорганизмы как потенциальные объекты биологического оружия предпринимались многими исследователями. Анализ критериально-рейтингового подхода к оценке вероятности использования биоагентов в качестве биологического оружия показал, что все биоагенты можно разделить на три группы. При этом необходимо сформулировать основные критерии, определяющие вероятность использования биоагентов в качестве биологического оружия и степень выраженности каждого из этих показателей. Например, в [2] степень выраженности показателей предложено определять по пятибалльной шкале для 30 видов патогенных бактерий, вирусов и токсинов. Полученные расчеты позволили «выстроить» биоагенты в соответствии с рейтингом (суммой баллов) и распределить их на три группы по степени вероятности использования в качестве биологического оружия (см. табл.).

К первой группе были отнесены возбудители, рейтинг которых был больше или равен 15, т. е. набравшие более 50 \% максимально возможных баллов. Вторую группу составили микроорганизмы, набравшие в сумме 10-14 баллов, т. е. 30-50\% от максимально возможных. В третью группу вошли возбудители, рейтинг которых меньше 10 баллов (меньше 30 \% максимально возможного количества баллов). На основании результатов проведенных расчетов можно утверждать, что с наибольшей вероятностью в качестве биологического оружия могут быть использованы биоагенты первой группы. Биоагенты второй группы, по всей вероятности, могут рассматриваться как потенциальные агенты, а биоагенты третьей группы не должны учитываться. 
Распределение биоагентов в соответствии с рейтингом

Distribution of bio-agents according to rate

\begin{tabular}{|c|c|c|c|c|c|}
\hline \multicolumn{2}{|l|}{ І ГРУППА } & \multicolumn{2}{|c|}{ II ГРУППА } & \multicolumn{2}{|c|}{ III ГРУППА } \\
\hline \multicolumn{2}{|l|}{ рейтинг >15 } & \multicolumn{2}{|c|}{ рейтинг 10-14 } & \multicolumn{2}{|c|}{ рейтинг < 10} \\
\hline возбудитель & рейтинг & возбудитель & рейтинг & возбудитель & рейтинг \\
\hline 1. Оспа & 26 & 12. Бруцеллез & 13 & 18. Бешенство & 8 \\
\hline 2. Чума & 23 & 13. Японский энцефалит & 13 & 19. Брюшной тиф & 7 \\
\hline 3. Сибирская язва & 21 & 14. Желтая лихорадка & 13 & 20. Дизентерия & 6 \\
\hline 4. Ботулизм & 21 & 15. Холера & 13 & 21. Стафилококк & 5 \\
\hline $\begin{array}{l}5 . \text { Вирусный энцефалит } \\
\text { лимфоцитарный }\end{array}$ & 20 & 16. Столбняк & 13 & 22. ВИЧ & 5 \\
\hline 6. Туляремия & 20 & 17. Дифтерия & 12 & & \\
\hline 7. Лихорадка Ку & 20 & & & & \\
\hline 8. Лихорадка Марбург & 18 & & & & \\
\hline 9. Грипп & 17 & & & & \\
\hline 10. Сап & 17 & & & & \\
\hline 11. Сыпной тиф & 15 & & & & \\
\hline
\end{tabular}

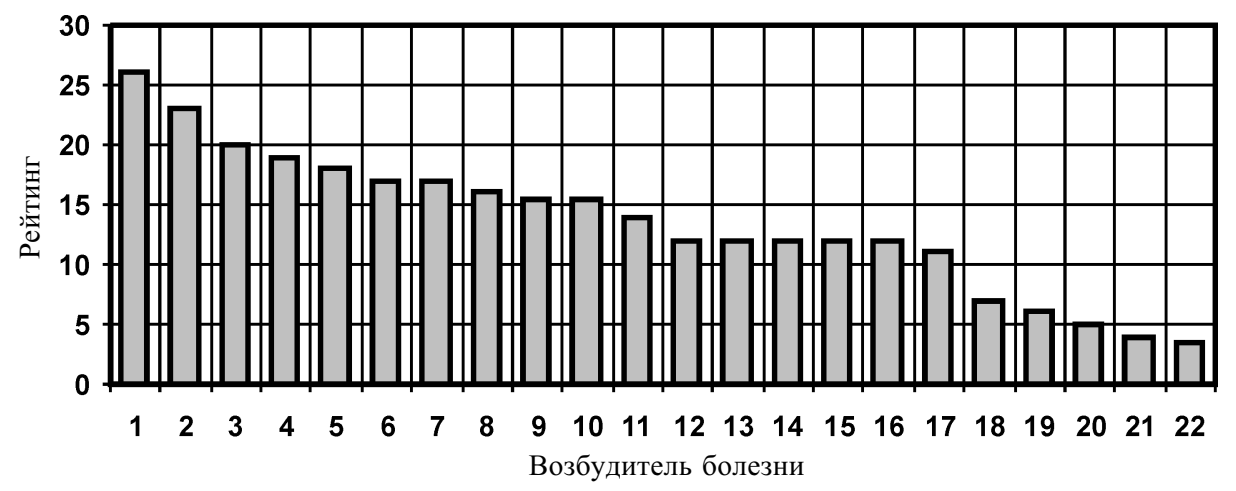

Вероятность использования биоагентов в качестве биологического оружия

Probability of using bio-agents as biological weapon

\section{3. Выводы}

Таким образом, потенциальной угрозе биотеррористической атаки подвергаются объекты с большим скоплением людей, а наиболее вероятными биоагентами являются оспа, чума, сибирская язва, ботулизм, геморрагические лихорадки. Для выявления и оценки обстановки, возникающей при совершении террористических актов с применением биоагентов, необходимо разработать программный комплекс, позволяющий в несколько раз сократить время работы на этапе при- нятия решения по защите населения и ликвидации последствий биологического заражения.

\section{Литература}

1. Свитнев, И. В.; Хмелев, В. Е. Современные террористические угрозы, чрезвычайные ситуации и безопасность жизнедеятельности. Учебное пособие. СПб.: СПбГУ, 2003. 188 с.

2. Воробьев, А. А. Непарентеральные методы иммунизации против оспы. Эпидемиол. и инфеки. бол., № 6, 2001, c. $54-56$.

\section{TERORO AKTŲ, KURIŲ METU PANAUDOJAMI BIOAGENTAI, SCENARIJŲ ANALIZE். BIOAGENTŲ KAIP BIOLOGINIO GINKLO PANAUDOJIMO TIKIMYBĖS İVRTINIMAS}

S. V. Kosyrev, I. V. Svitnev, A. G. Papin

$\mathrm{S}$ a n tra k a

Ivertinant biologinio terorizmo realumą ir mastą, straipsnyje nagrinëjamas vienas iš galimų variantų, kai teroristiniams tikslams panaudojamos sibirinès opaligès sporos. Autoriai pateikia mikroorganizmų kaip potencialaus biologinio ginklo užtaiso klasifikaciją. Atlika bioagentų panaudojimo teroristiniams tikslams tikimybės analizè. Labai svarbu suformuluoti pagrindinius kriterijus bioagentu panaudojimo tikimybei nustatyti bei šių kriterijų išraiškas. Teroristinès atakos ypač tikètinos ten, kur lankosi daug žmonių. Situacijos i̇vertinimo, i̇vykus teroro aktui, trukmei sutrumpinti būtina sukurti tam skirtą programinị kompleksą. 